\title{
Industrial Sugar Beets to Biofuel: Field to Fuel Production System and Cost Estimates
}

\author{
Choolwe Haankuku ${ }^{\mathrm{a}}$, Francis M. Epplin ${ }^{\mathrm{a}, *}$ and Gopal V. Kakani ${ }^{\mathrm{b}}$
}

${ }^{a}$ Department of Agricultural Economics, Oklahoma State University, Stillwater, OK 74078, USA

${ }^{\mathrm{b}}$ Department of Plant and Soil Sciences, Oklahoma State University, Stillwater, OK 74078, USA

*Corresponding author Tel.: +1 405-744-6156; fax: +1 405-744-8210

Email address: f.epplin@okstate.edu (F.M. Epplin). 


\section{Abstract}

Specialized varieties of sugar beets (Beta vulgaris L.) may be an eligible feedstock for advanced biofuel designation under the USA Energy Independence and Security Act of 2007. These non-food industrial beets could double ethanol production per hectare compared to alternative feedstocks. A mixed-integer mathematical programming model was constructed to determine the breakeven price of ethanol produced from industrial beets, and to determine the optimal size and biorefinery location. The model, based on limited field data, evaluates Southern Plains beet production in a 3-year crop rotation, and beet harvest, transportation, and processing. The optimal strategy depends critically on several assumptions including a just-in-time harvest and delivery system that remains to be tested in field trials. Based on a wet beet to ethanol conversion rate of $110 \mathrm{dm}^{3} \mathrm{Mg}^{-1}$ and capital cost of $128 \mathrm{M} \$$ for a $152 \mathrm{dam}^{3} \mathrm{y}^{-1}$ biorefinery, the estimated breakeven ethanol price was $507 \$ \mathrm{~m}^{-3}$. The average breakeven production cost of corn (Zea mays L.) grain ethanol ranged from 430 to $552 \$ \mathrm{~m}^{-3}$ based on average net corn feedstock cost of 254 and $396 \$ \mathrm{~m}^{-3}$ in 2014 and 2013, respectively. The estimated net beet ethanol delivered cost of $207 \$ \mathrm{~m}^{-3}$ was lower than the average net corn feedstock cost of 254 to $396 \$ \mathrm{~m}^{-}$ ${ }^{3}$ in 2013 and 2014. If for a mature industry, the cost to process beets was equal to the cost to process corn, the beet breakeven ethanol price would be $\$ 387 \mathrm{~m}^{-3}\left(587 \$ \mathrm{~m}^{-3}\right.$ gasoline equivalent).

Key words: Beta vulgaris, breakeven price, biorefinery, Brassica napus, canola, cooperative, crop rotation, energy beets, ethanol, industrial beets, Triticum aestivum, wheat 


\section{Introduction}

The USA Renewable Fuels Standard (RFS) legislation mandates the use (if produced) of $136 \times 10^{3} \mathrm{dam}^{3} \mathrm{y}^{-1}$ of renewable fuels by 2022 , of which $79 \times 10^{3} \mathrm{dam}^{3}$ would come from advanced biofuels. Advanced biofuels are classified as non-grain based biofuels including ethanol derived from lignocellulosic biomass such as timber chips and perennial grasses, ethanol from sugar crops, and ethanol derived from waste material including crop residues and urban waste [1,2]. Based on the USA Energy Independence and Security Act (EISA) of 2007, sugar beets (Beta vulgaris L.) may be an eligible feedstock for advanced biofuel provided that production and conversion to biofuel meets the $50 \%$ greenhouse gas reduction threshold required for advanced biofuel designation[1,2]. Prior to certification of a renewable fuel feedstock pathway, the USA Environmental Protection Agency (EPA) evaluates petitions for the lifecycle assessments of greenhouse gas (GHG) emissions (including emissions from land use change) of each proposed biofuel pathway. As of this writing, requests for assessment of industrial beets had been submitted to, and were under review by EPA [3]. Most ethanol produced in the USA is corn (Zea mays L.) grain based but a growing interest to diversify biofuel feedstock sources has encouraged field trial research of industrial beets across several geographical regions in the USA including the Southern Great Plains [4-7]. Interest in beets is growing also because sugar crops have successfully been used commercially for ethanol production in Europe (sugar beets) and in Brazil (sugar cane (Saccharum officinarum)) and have demonstrated great potential to lower GHG emissions than other feedstocks (corn, rapeseed (Brassica napus)) $[4,8]$.

USA sugar beets are predominantly grown in the northern plains and some parts of the central plains and far west. The 11 sugar beet producing states include North Dakota, Minnesota, Michigan, Wyoming, Montana, Colorado, Nebraska, Idaho, Washington, Oregon, and California 
[9]. Sugar beets perform well in temperate climate but due to genetic enhancement, the crop has proven to adapt to various soil and climatic conditions $[9,10]$. Sugar beets are tuber crops composed of about $75 \%$ water, $18 \%$ sugar (sucrose), and $7 \%$ insoluble and soluble materials (which are required to be at low levels). Unlike conventional sugar beets that are bred to produce sucrose for table sugar, biofuel feedstock industrial beets are specialized non-grade varieties bred for total sugar production. In addition to sucrose, these beets may produce glucose, fructose, maltose, and inverted sugars. Industrial beets are not required to be low in nitrogen, sodium, and potassium, enabling easier crop management. The presence of sugars in addition to sucrose, does not interfere with fermentation and distillation [11-13]. These non-food beets would not be efficient feedstock for the production of table sugar for human consumption, but are under development for industrial use including bioenergy production.

In the USA, conventional sugar beets produced for processing into edible sugar are heavily regulated. The USA sugar program uses marketing allotments to restrict domestic production of sugar cane and sugar beets [14]. Marketing allotments are assigned to seven processers that process beets contracted for production from the eleven beet producing states. The seven processers are Amalgamated Sugar Co., American Crystal Sugar Co., Michigan Sugar Co., Southern Minnesota Beet Sugar Cooperative, Minnesota-Dakota Farmers' Cooperative, Western Sugar Company, and Wyoming Sugar Growers Association [15]. Federal law caps the volume of sugar that can be sold in the USA by domestic sugarcane and sugar beet processors for domestic human consumption. For fiscal year 2014, overall sugar beet and sugar cane allotments were set at 4.8 and 4.1 billion $\mathrm{kg}$, respectively [15]. If domestic production and the Commodity Credit Corporation (CCC) inventory falls short of these quotas, then reassignment could be made to imports. A provision under the 2014 farm bill feedstock flexibility program 
permits the CCC to sell excess sugar for use as a bioenergy feedstock [14]. Contrary to conventional sugar beets, there is currently no federal restriction on the production and marketing of biofuel feedstock beets [6]. As such, it is anticipated that industrial feedstock beets could be legally grown and processed into biofuels in regions that do not have a sugar allotment such as the southern Great Plains.

Industrial beets are being considered for biofuel production because they have high sugar content and could potentially double ethanol production per hectare compared to other feedstocks (corn, cellulose) [16, 17]. In addition, the process to convert industrial beets to biofuel is known and relatively less complex than conversion of other potential advanced biofuels such as corn stover to ethanol $[16,18,19]$. However, to compete with other potential feedstocks for fulfilling the "advanced biofuels" mandate, the cost to produce biofuels from industrial beets must be competitive. Cost estimates are required to encompass the complete chain from the cost of bidding cropland from current use to the cost of marketing the biofuel. These cost estimates would be necessary to determine if an industrial beet-to-biofuel system would be able to compete with other advanced biofuel alternatives as defined by EISA.

Several studies have evaluated the economic feasibility of the production of ethanol from sugarcane and sugar beets [16, 19-24]. These studies have produced different conclusions depending on the geographic region and the assumptions made. In addition to feedstock yield and price assumptions, the number of days per year during which the biorefinery can operate at full capacity is critical to the overall economics. A plant with a shorter processing window would have relatively greater capital costs per unit processed.

Maung and Gustafson [19] calibrated a stochastic simulation financial model using sugar beet yield data in North Dakota to examine the economic feasibility of producing ethanol from 
sugar beets. They used a conversion rate of about $110 \mathrm{dm}^{3} \mathrm{Mg}^{-1}$ for two plant sizes ( $38 \mathrm{dam}^{3}$ and $76 \mathrm{dam}^{3}$ per year) that they assumed could process 333 days per year. The reported breakeven ethanol price ranged from $400 \$ \mathrm{~m}^{-3}$ and $450 \$ \mathrm{~m}^{-3}$ for the larger and smaller sized plants, respectively. For Washington state, Yoder et al. [10] found that the production of sugar beets failed to cover production costs and or transportation costs and concluded that the conversion of both raw beet juice and beet pulp to ethanol was not profitable under Washington agronomic and economic conditions. The estimated breakeven ethanol price was about $560 \$ \mathrm{~m}^{-3}$ (beet acquisition and processing) when a more cost efficient conversion process was considered. Similarly, a study by the USDA [16] for a plant operating about 180 days per year found that ethanol production from sugar beets could only be profitable in the USA if the market price of ethanol was no less than $1060 \$ \mathrm{~m}^{-3}$. For comparison, the production cost of European ethanol from beets was reported to range from $574-740 \$ \mathrm{~m}^{-3}[22-24]$. However, the estimated cost of $159 \$ \mathrm{~m}^{-3}$ to produce ethanol from Brazilian sugar cane is substantially less than that estimated for USA or European beet ethanol [22].

Prior studies have produced cost estimates for regions in which sugar beets or sugar cane are currently grown to produce sugar (in USA) and or ethanol (in Brazil and Europe). The expected cost to produce beets in nontraditional sugar beet production regions such as the southern Great Plains is unknown. The objective of the current study is to determine the most economically efficient industrial beet field-to-biofuel system that can be envisioned for conditions in a case study region of Oklahoma. In particular, a model is developed to determine the most cost-efficient feedstock production system, to include description of crop rotations, location of production, location and size of the biorefinery, harvest timing and number of harvest machines, feedstock transportation flows and product sales. The model is designed to estimate 
specific costs along the entire value chain. The research presented in this study will contribute towards ongoing research in assessing the economic viability of ethanol production from a biorefinery that uses industrial beets exclusively.

\section{Conceptual Framework}

About 4.2 million hectares are planted to annual crops in the case study region of Oklahoma. Winter wheat (Triticum aestivum) is the main crop with 2.2 million hectares. Some producers rotate winter wheat with winter canola (Brassica napus). Grain sorghum (Sorghum bicolor) is also grown in the region and may be no-till planted into wheat stubble immediately after wheat grain harvest [25].

Oklahoma has not had a sugar beet allotment and beets have not been grown in Oklahoma. A limited number of field trials have found that some specialized non-grade varieties of beets bred for high sugar content may produce reasonable yields $\left(53.1 \mathrm{Mg} \mathrm{ha}^{-1}\right)$ in Oklahoma $[5,13]$ which are comparable to dryland beet trial yields in North Dakota (56.5 $\mathrm{Mg} \mathrm{ha}^{-1}$ ) [26]. In regions of mild winters beets may be seeded in the fall. Based on field trials in the region of the study, planting beets prior to the first week of November enables plants to become established and be at the 8-10 leaf stage prior to the onset of winter. These plants survive winter weather encountered in the region [5]. The beets may be harvested as early as June, or they may be left in the ground and harvested as late as March of the following year. This wide 10-month harvest window would enable a just-in-time harvest and delivery system for at least 300 days per year. Zhang et al. [27] reported harvesting healthy looking beets that had been maintained in the ground for over 12 months. The fixed costs of harvest and transportation machines could be spread over a substantial number of hectares. Since the beets could be left in the field until 
required for processing, storage requirements and storage costs for harvested beets would be minimal.

A business plan for an industrial beet biorefinery in the Southern Plains could be formulated similar to the closed-membership (also called "new generation") producer cooperative system used for food sugar beets in the Northern Plains. The closed-membership cooperative could build and manage the biorefinery as is the case with some corn ethanol plants in the USA Corn Belt. An Oklahoma industrial beet new generation cooperative would require a predetermined amount of resources and pledges of feedstock from its members [28, 29]. The cooperative could contract with farmers by selling delivery rights shares to potential growers. The contract between the grower and the cooperative would obligate farmers to grow and deliver beets from a specified number of hectares over a specified number of years [30]. In northwest Oklahoma, a successful closed-membership producer cooperative to market frozen wheat dough was established in 1999. This member owned cooperative required its members to invest about $\$ 5,000$ and provide at least $37 \mathrm{Mg}$ of wheat per year [31]. However, since farmers in Oklahoma do not have a history of growing beets, a beet based biorefinery cooperative could be difficult to implement in Oklahoma. Prior to putting together a business plan that would be required to entice farmers to invest in a producer cooperative designed to produce advanced biofuels, it would be prudent to determine if an industrial beet based biorefinery would be a viable enterprise.

It is recommended that the beets be grown in a 3-5 year rotation with other crops, such as grains, to improve soil fertility and manage diseases and nematodes [10]. In Oklahoma, beets could be grown in a three-year rotation with crops such as winter wheat, winter canola, and grain sorghum. One option for a three-year rotation would be to harvest wheat in June followed by 
seeding beets in October, to be harvested in June through September, after which either wheat or canola could be sown. However, some beets could be left in the ground beyond September until the following March and harvested as needed. Thus, wheat could be harvested in June and beets could be seeded in October. The harvest window could extend from June through to March of the following year. On those hectares in which the presence of unharvested beets prevents the seeding of a fall crop, grain sorghum could be seeded in the spring and harvested in the summer enabling canola or wheat to be planted in the fall (Figure 1). The 10-month harvest window would greatly reduce the cost to store harvested beets [32].

An extended harvest window does impose some potential challenges. The management team and producer members would have to agree on a harvest schedule that would both (a) enable the farmers to plan their subsequent crops and (b) appropriately compensate for the extended use of land on which harvest is delayed. These details could be negotiated and specified in the closed-membership producer cooperative contracts.

\section{Methods}

\subsection{Model}

A multi-region multiple period mixed integer mathematical programming model [33-35] was developed to determine the breakeven price of ethanol from industrial beets. The objective function of the model is to maximize the net present value of producing and procuring beet feedstock for conversion to ethanol. The model selects the location and size of the biorefinery, modeled as binary variables that will maximize the net present value. The model is designed to select from one of three potential biorefinery sizes that reflect size economies and accounts for the cost of transporting beets from the field as a function of distance from the biorefinery. Thus, it addresses the tradeoff between feedstock transportation cost as a function of distance and 
biorefinery cost as a function of size. The model (Appendix A) was executed in GAMS (generalized algebraic modeling system) using the CPLEX solver. An iterative grid search technique was employed to determine the breakeven price of ethanol at which the net present value of the production process is zero. The model was solved for combinations of three capital requirements and three proportions of total available cropland that may be seeded to beets in each county annually.

\subsection{Data and Assumptions}

\subsubsection{Feedstock Production and Harvest}

The study considers 35 Oklahoma counties as potential beet production regions. The counties were selected based on counties that have substantial hectares of winter wheat [25] since it is expected that beets would be grown in rotation with wheat. Eight of these counties were considered as prospective locations for the biorefinery (Figure 2). The potential plant locations were selected based on availability of road infrastructure and beet yield potential of the producing regions [34].

The study used average beet yield produced from designed field experiments in Caddo, Grady, and Payne counties over three years (2010-2013) to synthesize yields for 32 other Oklahoma counties. Based on these field trial data, an estimate of the beet yield as a function of total rainfall from the month prior to seeding the beets (September) to the month before initial harvest (August, May, and June in 2 011, 2012, and 2013, respectively) found that yield responded positively to rainfall (though not significant, P-value $=0.48)($ Table 1$)$. Some studies have used nonlinear functional forms to estimate crop yield response to climate variables [36, 37]. However, due to data limitations for the present study, a linear model was estimated. Vagh [38] and Freckleton et al. [39] concluded that while other factors were important, crop 
production is closely related to annual rainfall. Thus a 30-year county level average of total

September through August precipitation data from the Oklahoma Mesonet website was obtained and used to compute the relative magnitude of annual precipitation of one county to another. The average yield from the three counties (Caddo, Grady, and Payne) was then used to synthesize yields for each of the remaining 32 counties based on the proportion of total September through August precipitation. The expected beet yield was greater in counties with greater average precipitation compared to counties with a lower precipitation. The implicit assumption was that moisture would be the most limiting factor. Given the paucity of available field trials and that fields across different counties could be expected to be subjected to various agronomic and edaphic conditions, a sensitivity analysis for $50 \%$ greater and $25 \%$ lower yields was included.

The model was designed to include a three-year beet crop rotation activity that was modeled to require three land units. The proportion of county available cropland in each year that could be bid to beet production is unknown. Thus, three scenarios were modeled. It was assumed that the proportion of land that would be allocated to the three-year crop rotation that includes one year of beet production was limited to no more than 15,30 and 60 percent of the total county available cropland in each year. This assumption restricts beet production to be no more than 5 , 10 and 20 percent of the total cropland in any county in any year. The total available cropland in each county was based on the 2007 agriculture census [40].

It was assumed that beets would be seeded in October with harvest beginning in June and extending through March of the following year (Figure 1). This is consistent with the conceptual framework that beets could be delivered just-in-time to the biorefinery for ten months each year. The beets would be left in the field below ground until harvested as needed for processing. The opportunity cost charged for land use would include the cost of biding land from its current use. 
229 An annual land rental rate of $158 \$ \mathrm{ha}^{-1}$, which is double the land rental rate of cropland in 230 Oklahoma [25], was budgeted for beet production. An additional $158 \$ \mathrm{ha}^{-1}$ was assessed for land on which beet harvest was delayed beyond the normal crop year. A yield adjustment factor (YAD), which is the proportion of potential yield recovered in each harvest month, was assumed to be one in the months of June and July. The value of YAD was assumed to decline by 0.05 per month from October until March [13]. For the months of April and May, YAD was set equal to zero, informing the model that beets are not available for harvest in these months.

The quantity of beets and hectares of land harvested depend on both the capacity of harvest machines and the available field days in that particular month. Harvest workdays were based on Hwang et al. [41] who used historical weather data to estimate the number of suitable workdays for each month for Oklahoma counties. Beet harvesting requires soil conditions favorable for machine travel and for topping and lifting the beets. Beet leaves may be left on the field on harvest for soil cover and compost [4]. For the present study, a $447 \mathrm{~kW}$ self-propelled 12 row, $0.56 \mathrm{~m}$ row-width, $25.4 \mathrm{Mg}$ tank, beet harvester with an estimated throughput of three hectares per hour was budgeted [42]. The monthly capacity of the beet harvester was estimated for each month in which harvest was permitted based on the available harvest work days for that month as computed by Hwang et al. [41]. The harvested beets are assumed to be offloaded from the harvester's tank to a delivery truck for direct transportation to the biorefinery. The total number of harvesters required was modeled as an integer variable and was endogenously determined by the model. The beet harvesters could either be owned by the cooperative or the entire harvest operation could be outsourced. In either case, a coordinated harvest schedule would be required to allocate the use of the harvesters across land area for the duration of the 10- 
month harvest window and to insure a steady flow of beets to the biorefinery. A crop budget for the production of industrial beets in Oklahoma is presented in Table 2.

\subsubsection{Transportation Cost Assumptions}

The model is based on the assumption of a just-in-time delivery strategy in which the beets would be harvested and shipped as needed to the biorefinery. This strategy would require coordination by the cooperative management team and members. The transportation cost equation was based on Wang's model [43] for transporting feedstock by road on trucks from the production fields to the processing facility. The distances from the region of production to the candidate cooperative biorefinery location were based on mid-point cities in each potential production and processing county.

\subsubsection{Facility Related Assumptions}

The model considered three biorefinery sizes based on processing capacity of $38 \mathrm{dam}^{3}$, $76 \mathrm{dam}^{3}$, or $152 \mathrm{dam}^{3}$ for the 300 days a year when the plant is operational. The assumed base level industrial beet to ethanol conversion rate was $110 \mathrm{~m}^{3} \mathrm{Mg}^{-1}$ based on a sugar recovery rate of $18 \%$ of wet beets [19]. A processing plant with capacity to process $76 \mathrm{dam}^{3}$ was assumed to be medium size. A factor of 0.5 was used to increase or decrease the processing facility capacities to other plant sizes. The capital costs associated with these facilities would vary by plant size. For a project in its feasibility stage, Dysert [44] and Gallagher et al. [45] propose an industry specific capacity factored estimate which uses a proration factor to define the nonlinear relationship between plant capacity and investment cost. A proration factor of 0.73 for an ethanol plant [44] was used for the present study. With a scaling exponent of 0.73 , doubling the plant capacity would increase construction costs by about $66 \%$. 
field with no facility for storage at the plant. The beets are washed, sliced and fed into an extractor to extract raw sugar juice by diffusion. The pressed beet pulps are co-products that may be used as a livestock feed [8]. Beet pulps are assumed to have a value of $79 \$ \mathrm{~m}^{-3}$ of ethanol $[20,22]$. The extracted raw juice from industrial beets contains not only sucrose, but other sugars (glucose, fructose, maltose, and inverted sugars) that are also fermentable using yeast. The raw juice is filtered through lime to remove impurities. During the fermentation phase, yeast is added to the raw sugar juice to produce ethanol. Natural gas is used for heating during the distillation process in which the ethanol is separated from water [8].

Based on average capital cost estimates of beet ethanol plants reported by prior studies [19-21], the capital investment costs for $38 \mathrm{dam}^{3}, 76 \mathrm{dam}^{3}$, and $152 \mathrm{dam}^{3}$ per year plants that operate for the assumed 10 months in a year was estimated to be $\$ 46, \$ 77$, and $\$ 128$ million, respectively. Annual operating and maintenance costs were based on Shapouri and Salassi and Yoder et al. [16, 20]. The biorefinery was assumed to have an expected life of 20 years. The parameters used in the model are presented in Table 3. The analyses were repeated for half and double the investment cost at a discount rate of $15 \%$ and $7.5 \%$. The model was also estimated for $25 \%$ lower and $50 \%$ greater beet yields and for double the land opportunity cost.

\section{Results}

\subsection{Breakeven Price of Ethanol}

The base model determined that it would be optimal to establish a $152 \mathrm{dam}^{3} \mathrm{y}^{-1}$ plant located in Grady County (Figure 3). The breakeven price of ethanol for three land proportions and three plant investment cost combinations are reported in Table 4. For the base case when beet production is limited to no more than $10 \%$ of the total county available cropland in each 
year and a plant investment cost of $128 \mathrm{M} \$$, the estimated breakeven price of ethanol for the 152 dam $^{3} \mathrm{yr}^{-1}$ plant is $586 \$ \mathrm{~m}^{-3}$ (about $890 \$ \mathrm{~m}^{-3}$ gasoline equivalent). If the cost to establish the plant is reduced from 128 to $64 \mathrm{M} \$$, the breakeven ethanol price reduces by $69 \$ \mathrm{~m}^{-3}$ to $518 \$ \mathrm{~m}^{-}$ ${ }^{3}$. If the biorefinery investment cost is increased from 128 to $256 \mathrm{M} \$$, the breakeven ethanol price increases by $137 \$ \mathrm{~m}^{-3}$ to $724 \$ \mathrm{~m}^{-3}$. Doubling the total county available cropland for beet production in each year from $5 \%$ to $10 \%$ and from $10 \%$ to $20 \%$ reduces the breakeven ethanol price by 24 and $8 \$ \mathrm{~m}^{-3}$ respectively (Table 4 ). The estimated breakeven price of beet ethanol ranges from 526-557 $\$ \mathrm{~m}^{-3}$, a decrease of $50 \$ \mathrm{~m}^{-3}$ when the discount rate is reduced from $15 \%$ $7.5 \%$ for the $128 \mathrm{M} \$$ capital cost. The net breakeven price of ethanol for the base case after accounting for beet pulp byproduct credits valued at $79 \$ \mathrm{~m}^{-3}$ was $507 \$ \mathrm{~m}^{-3}$. The present findings are comparable to cost estimates reported by prior studies ranging from $400 \$ \mathrm{~m}^{-3}$ to $620 \$ \mathrm{~m}^{-3}$ $[14,16,20]$.

Table 5 presents the cost components of the breakeven price of beet ethanol for three land proportions and three levels of plant investment cost. Plant capital and processing cost, beet field production cost (seed, fertilizer and herbicides), and transportation cost were among the top three expenses to produce ethanol from beets. The cost components of the breakeven ethanol price of $586 \$ \mathrm{~m}^{-3}$ includes $55 \$(9 \%)$ for land rental (including grower compensation for delaying harvest beyond September), $142 \$(24 \%)$ for field production cost, $27 \$(5 \%)$ for harvest cost, $62 \$(11 \%)$ for transportation cost, and $301 \$ \mathrm{~m}^{-3}(51 \%)$ for plant investment and processing cost.

\subsection{Cost of Delivered Feedstock}

For the base scenario, the cost to deliver a continuous flow of beet feedstock to a biorefinery was $31.01 \$ \mathrm{Mg}^{-1}\left(286 \$ \mathrm{~m}^{-3}\right)$ (Table 6). The cost to produce and deliver beet feedstock ranged from $33.39 \$ \mathrm{Mg}^{-1}$ to $29.96 \$ \mathrm{Mg}^{-1}$ when the proportion of the total county 
cropland available for beet production in each year was $5 \%$ and $20 \%$ respectively. This decrease in the estimated total feedstock delivered cost can be noted in the reduction of transportation cost from $8.01 \$ \mathrm{Mg}^{-1}$ when only $5 \%$ of county cropland is used for beet production each year to 5.91 $\$ \mathrm{Mg}^{-1}$ when the available land each year is increased to $20 \%$. Field production cost of $15.45 \$$ $\mathrm{Mg}^{-1}\left(142 \$ \mathrm{~m}^{-3}\right)$ and transportation cost of $6.71 \$ \mathrm{Mg}^{-1}\left(62 \$ \mathrm{~m}^{-3}\right)$ accounted for a larger proportion (50\% and $22 \%$ respectively) of total delivered beet cost of $31.01 \$ \mathrm{Mg}^{-1}\left(286 \$ \mathrm{~m}^{-3}\right)$. The harvest cost was $2.91 \$ \mathrm{Mg}^{-1}\left(27 \$ \mathrm{~m}^{-3}\right)$ and base land rental cost was $5.94 \$ \mathrm{Mg}^{-1}\left(55 \$ \mathrm{~m}^{-3}\right)$. The estimated land rental cost would have to be sufficient not only to bid land from its alternate use, but also to compensate growers for maintaining beets in the field until harvested.

The model determined that about 1.37 million wet $\mathrm{Mg}$ of beet feedstock would be required by the biorefinery, approximately 4,600 wet $\mathrm{Mg}$ per day for the ten months processing period in a year. The system would require that $18025-\mathrm{Mg}$ truckloads of wet beets be delivered every day during the 300-day processing window; seven trucks per hour, one every 8.56 minutes. The feedstock would be harvested from a total of 31,748 ha (about $0.3 \%$ of total cultivated cropland in Oklahoma in 2012) from among nine counties (Table 6 and Figure 3). Further research would be required to determine the beet yield consistency over an extended harvest window including the assumption of a 5\% yield decline for each month the beets are maintained in the field after September. The harvested land was 31,402 ha and 33,499 ha when the proportion of the total county cropland available in each year for beet production was $20 \%$ and $5 \%$, respectively. The harvested land was lower for the $20 \%$ available land proportion $(31,402$ ha) than the $10 \%$ land proportion (31,748 ha) since the model optimized production costs by contracting additional land in counties with higher yields in the vicinity of the biorefinery to achieve lower transportation cost. 


\subsection{Sensitivity to Yield and Land Cost}

If breeders developed varieties with $50 \%$ greater yields, the feedstock delivered cost would reduce by $25 \%$ from the base level of $31.01 \$ \mathrm{Mg}^{-1}$ to $23.28 \$ \mathrm{Mg}^{-1}$ (Table 6). The present study is based on limited field data. Further research would be required to identify varieties suitable for beet production in Oklahoma and to examine optimal agronomic practices and yield consistency over time. Sensitivity results show that the feedstock delivered cost is $38.96 \$ \mathrm{Mg}^{-1}$ (a $26 \%$ increment) when beet yields were decreased by $25 \%$. Doubling the land rental cost from the base level of 158 to $316 \$ h^{-1}$ increased the cost to produce and deliver feedstock by $20 \%$ from 31.01 to $36.92 \$ \mathrm{Mg}^{-1}$.

\section{Discussion}

The objective of the study was to estimate the breakeven price of ethanol for a biorefinery that is designed to use industrial beet feedstock exclusively, and to determine the optimal size and plant location. The model considered beets in a 3-year rotation including a justin-time ten month harvest strategy. Based on the assumptions of the study, the model determined that it was optimal to establish a $152 \mathrm{dam}^{3} \mathrm{yr}^{-1}$ plant in Grady County. For a conversion rate of $110 \mathrm{dm}^{3} \mathrm{Mg}^{-1}$ and an investment cost of $128 \mathrm{M} \$$, the breakeven price of ethanol was estimated to be $507 \$ \mathrm{~m}^{-3}$ after byproduct credits are taken into account. At present, there is no established advanced biofuel biorefinery operating in Oklahoma. However, based on Abengoa, the only known operating advanced biofuel plant in the region, the cost to produce a cubic meter of ethanol from corn stover is approximately $608 \$ \mathrm{~m}^{-3}$ [46]. Haque and Epplin [35] estimated similar ethanol breakeven prices $\left(560-720 \$ \mathrm{~m}^{-3}\right.$ ) for producing ethanol from cellulosic feedstocks in the region. 
For the base model, the estimated net feedstock delivered cost for beets is $207 \$ \mathrm{~m}^{-3}$ of ethanol. This delivered beet feedstock cost is lower than the average net corn feedstock cost that ranged from $396 \$ \mathrm{~m}^{-3}$ to $254 \$ \mathrm{~m}^{-3}$ from 2013 to 2014 [47]. Based on the Iowa State model [47], total variable and fixed cost for ethanol production other than the corn feedstock cost is $180 \$ \mathrm{~m}^{-}$ 3. If the cost to process beets was equal to the cost to process corn, since theoretically it should be easier to process beets into ethanol than to process corn grain into ethanol (assuming a mature industry, and that beets could be harvested and delivered over a 10 month period, the expected cost to process beets into ethanol should be no more than the cost to process corn grain into ethanol), the breakeven cost would be $207 \$+180 \$=387 \$ \mathrm{~m}^{-3}\left(587 \$ \mathrm{~m}^{-3}\right.$ of gasoline equivalent). This suggests that under these circumstances, the cost to produce ethanol from beets may be cheaper than the average cost of ethanol production from corn grain for 2013-2014 (430 to $552 \$ \mathrm{~m}^{-3}$ based on corn grain base price of 160 to $\left.240 \$ \mathrm{Mg}^{-1}[47,48]\right)$. Shapouri and Salassi [16] point out that the capital cost to construct facilities to produce beet ethanol would be expected to be higher than capital costs for corn grain based ethanol plants mainly because of the higher cost of pre-processing beet feedstock. The nascent beet-based ethanol industry modeled in the present study with total plant and processing cost of $301 \$ \mathrm{~m}^{-3}$ (processing cost of $164 \$ \mathrm{~m}^{-3}$ $[16,20]$ and an amortized capital cost of about $137 \$ \mathrm{~m}^{-3}$ (investment risk of 15\%)) is less competitive than corn ethanol and would likely face difficulties finding investors.

Further, the production of industrial beets would be highly dependent on farmers and management of a cooperative for hundreds of producers in various production regions (counties) would not be a trivial task. Implementing a closed-membership cooperative would be challenging in regions such as Oklahoma that have limited experience with closed-membership cooperatives, and have no history of growing beets. 
For the base model, about 31,748 ha of land would be required to supply beets to the

biorefinery for the 10 month processing window. Assuming that each member of the cooperative agreed to plant 32 ha of beets each year, the cooperative would need 990 members to supply the beets to the biorefinery. If the capital investment cost for the $152 \mathrm{dam}^{3}$ per year biorefinery is $128 \mathrm{M}$, and $7 \mathrm{M} \$$ for harvest machines, and several more millions for trucks, an investment of $150 \mathrm{M} \$$ may be required to establish the business. If $50 \%$ of the investment cost could be financed by borrowing, an investment of $\$ 76,000$ would be required from each of 990 farmer members to form the cooperative. Given that none of the farmers have experience growing beets, and given the uncertainty of yields, revenue, and production costs, obtaining this level of investment from 990 potential members could be very difficult especially if profitability depends on government policy that could be changed.

The optimal strategy presented herein depends critically on several assumptions including: (a) public policy would enable the production of industrial beets in Oklahoma; (b) a closed-membership producer cooperative could be formed; (c) a scheme could be developed that would entice members to agree to permit the manager of the cooperative to schedule harvest over a 10 month harvest window; (d) members would agree to a differential payment system that would incentivize some producers in some cases to forgo crop production in a field in which beets from the previous growing season were awaiting harvest; (e) in years of excess production a system would be necessary to compensate members whose beets are not used; and (f) beet yields obtained in the limited field trials conducted in the region to-date are achievable across the region. These assumptions to facilitate the production of ethanol from beets grown in Oklahoma remain to be validated. 


\section{Acknowledgement}

The authors acknowledge the assistance of resources provided by the Oklahoma

Agricultural Experiment Station. Additional funding was provided by the USDA-NIFA, USDA-

DOE Biomass Research and Development Initiative, Grant No. 2009-10006-06070. The project

was also supported by the USDA National Institute of Food and Agriculture, Hatch grant number H-2824, and by the Jean \& Patsy Neustadt Chair. Support does not constitute an endorsement of the views expressed in the paper by the USDA.

\section{Appendix A}

The mathematical model used in the study and presented in this appendix is an adaptation of models presented in prior studies [31-33]. A description of the set elements, the variables, and model parameters are reported in Tables A1, A2, and A3, respectively. The objective function of the multi-region multiple-period mixed integer mathematical programming model was specified as:

$$
\begin{gathered}
\max _{Q_{j s m,} A_{i m}, X T_{i j s m, X}} N V_{j s m,}=\left\{\sum_{m=1}^{M}\left(\sum_{j=1}^{J} \sum_{s=1}^{S} \rho Q_{j s m}-\sum_{i=1}^{I} \delta A_{i m}-\sum_{i=1}^{I} \sum_{j=1}^{J} \sum_{s=1}^{S} \tau_{i j} X T_{i j s m}\right)\right. \\
\left.-\sum_{j=1}^{J} \sum_{s=1}^{S} O M C_{s} \beta_{j s}-\gamma H\right\} * P V A F-\sum_{j=1}^{J} \sum_{s=1}^{S} A F C_{s} \beta_{j s}
\end{gathered}
$$

Where $P V A F=(1+r)^{T}-1 / r(1+r)^{T}$ is the annuity factor. Initial capital outlay to establish the biorefinery is assumed to occur in year zero. Annual beet production occurs from year 1 to 

harvested.

$$
A_{\text {im }}=0 \text { if } Y A D_{m}=0, \forall_{i, m}
$$
in each year. The quantity of total cropland allocated to beet production in each year after accounting for the 3-year crop rotation was restricted to no more than $10 \%(B I P R O P=10 \%)$ (under the base model) of the total available cropland in each region of production (equation 2). year. produced on harvested cropland.

$$
X_{i m}-A_{i m} B Y L D_{i} Y A D_{m}=0, \quad \forall_{i, m}
$$
rotation was limited to no more than 15,30 and 60 percent of the total county available cropland The analysis was repeated for a $5 \%$ and $20 \%$ proportion of available cropland in each county per 

current harvested quantity from each county for each month.

$$
\sum_{i=1}^{I} \sum_{m=1}^{M} X_{i m}-\sum_{j=1}^{J} \sum_{m=1}^{M} X T_{i j s m}=0, \forall_{i, m}
$$

The biorefinery processing capacity has a monthly limitation at each potential location as 450 shown in equation (6)

$$
Q_{j s m}-C A P P_{s} \beta_{j s} \leq 0, \forall_{j, s, m}
$$

451

452 7).

$$
\sum_{I=1}^{I} \sum_{m=1}^{M} X T_{i j s m}-\sum_{m=1}^{M} X P_{j s m}=0, \forall_{j, s, m}
$$

A constraint that the monthly ethanol production does not exceed the capacity of the biorefinery is imposed in Equation (8)

$$
Q_{j s m}-\lambda X P_{j s m} \leq 0, \forall_{j, s, m}
$$

457 In equation (9), the number of endogenously determined beet harvesters in any month is 458 restricted to be equal or less than the number of harvesters available

$$
\sum_{i=1}^{I} X H_{i m}-H \leq 0, \forall_{m}
$$

In equations (10) and (11) each month's harvested beet feedstock is less than the

461 harvesting capacity of the total number of harvesters. 


$$
\sum_{l=1}^{L} X_{i m}-X H_{i m} C A P H_{i m} \leq 0, \forall_{i, m}
$$
machine in month $\mathrm{m}$ by the number of available field days.

$$
C A P H_{i m}=F W D_{i m} D C A P H_{m}, \forall_{m}
$$
set to be a non-negative integer value.

$$
Q_{j s m}, A_{i m}, X T_{i j s m} X P_{j s m}, X_{i m}, H \geq 0
$$

$$
\beta_{j} \in\{0,1\}
$$

467 The sugar beet model consists of 2,831 equations and 12,903 activities. 


\section{References}

[1] Congress. U.S. Renewable Fuels, Consumer Protection, and Energy Efficiency Act of 2007. Section 102, Subtitle A, H.R. 6 (EAS). 2007.

[2] National Renewable Energy Laboratory (NREL) [Internet]. State and local governments: renewable fuel standards. 2014 [Updated 08.09.14; cited 10.02.15] Available from: http://www.nrel.gov/tech_deployment/state_local_governments/basics_fuel_standards.ht $\mathrm{ml}$

[3] U.S. Environmental Protection Agency (EPA) [Internet]. Fuel pathway petitions: Under EPA review. 2015 [Updated 21.05.15; cited 22.05.15] Available from: http://www.epa.gov/otaq/fuels/renewablefuels/new-pathways/rfs2-pathways-review.htm

[4] Panella L. Sugar beet as an energy crop. Sugar Tech 2010;12(3-4):288-293.

[5] Kakani VG, Godsey CB, Wagle P, Foster AJ, Kakani A, Sripathi R, et al. Energy beets as a bioenergy feedstock in Southern Great Plains. Proceedings of the National Conference of Science for Biomass Feedstock Production and Utilization; 2012 October 2-5; New Orleans, LA.

[6] Dorminey B [Internet]. Ethanol from energy beets: A viable option? 2014[Updated 2014; cited 07.02.15] Available from: http://www.renewableenergyworld.com/rea/news/ article/2014/04/ethanol-from-energy-beets-a-viable-option.

[7] Capehart T, Schnepf R, Yacobucci BD. Biofuels Provisions in the 2007 Energy Bill and the 2008 Farm Bill: A Side-by-Side Comparison. CRS Report for Congress, RL34239, June 2008.

[8] Halleux H, Lassaux S, Renzoni R, Germain A. Comparative life cycle assessment of two biofuels ethanol from sugar beet and rapeseed methyl ester. Int. J. LCA 2008;13 (3):18490

[9] U.S. Department of Agriculture [Internet]. Sugars and Sweetners. 2011[Updated 11.14; cited 10.01.15] Available from: http://www.ers.usda.gov/topics/crops/sugarsweeteners.aspx

[10] Ali MB. Characteristics and production costs of US sugar beet farms: United States Department of Agriculture Statistical Bulletin SB974-8; 2004.

[11] Duke JA [Internet]. Handbook of energy crops. 1983[Updated 30.12.97; cited 12.05.15] Available form: https://www.hort.purdue.edu/newcrop/duke_energy/Beta_vulgaris.html

[12] Adams T[Internet]. Research into Energy Beets includes EPA classification, crop insurance. 2013[Updated 14.03.13; cited 04.01.15] Available from: http://www.theprairiestar.com/news/crop/research-into-energy-beets-includes-epaclassification-crop-insurance/article_8cb12eec-8754-11e2-83c2-001a4bcf887a.html

[13] Kakani VG. 2014. Assistant Professor, Bioenergy Crop Production . Department of Plant and Soil Sciences.Personal communication. Oklahoma State University; 2014.

[14] U.S. Department of Agriculture [Internet]. Sugar loan program, sugar marketing allotments and feedstock flexibility program. Farm Bill fact sheet. 2014a [Updated 2014; cited 04.01.15] Available from: http://www.fsa.usda.gov/Internet/FSA_File/sugar_loan_2014.pdf 
[15] U.S. Department of Agriculture[Internet]. News release: USDA reassigns Fiscal Year 2014 sugar allotments. News release No.0100.14. 2014b. [Updated 2014; cited 04.01.15] Available from: http://www.fsa.usda.gov/FSA/newsReleases?area=newsroom\&subject=landing\& topic $=$ ner\&newstype $=$ newsrel\&type $=$ detail\&item $=$ nr_20140530_rel_0100.html

[16] Shapouri H, Salassi ME. The economic feasibility of ethanol production from sugar in the United States.Washington DC:USDA-ERS; 2006 July.69 pp.

[17] Panella L, Kaffka SR. Sugar beet (Beta vulgaris L) as a biofuel feedstock in the United States. In: Eggleston, G. editor. Sustainability of the sugar and sugar ethanol industries. ACS Symposium Series, vol. 105. Washington, DC: American Chemical Society; 2010. p. $163-175$.

[18] Robb T. Biomass derived energy Southwest Ks Project. Proceedings of the Kansas Renewable Energy Conference; 2007 September 25-26; Topeka, Kansas. Available from: http://www.powershow.com/view/96315-YTkzM/Biomass_derived_energy_Southwest _KS_Project_powerpoint_ppt_presentation

[19] Maung TA, Gustafson CR. The economic feasibility of sugar beet biofuel production in central North Dakota. Biomass Bioenerg 2011;35(9):3737-47.

[20] Yoder J, Young D, Painter K, Chen J, Davenport J, Galinato S. Potential for a sugar beet ethanol industry in Washington state. Report submitted to the Washington State Department of Agriculture Online Available from: http://agr wa gov/AboutWSDA/Docs/ EthanolfromWASugarBeetsWSUStudyMarch2009 pdf, 2009[Accessed January 2011].

[21] Ripplinger D. Assistant Professor, Department of Agribusiness and Applied Economics. Personal communication. North Dakota State University; 2014.

[22] Goldemberg J. The Brazilian biofuels industry. Biotechnol Biofuel 2008 May;1:1-7

[23] Balat M, Balat H. Recent trends in global production and utilization of bio-ethanol fuel. Applied Energy 2009 April;86:2273-82.

[24] Murphy J, McCarthy K. Ethanol production from energy crops and wastes for use as a transport fuel in Ireland. Applied Energy 2005;82(2):148-166.

[25] U.S. Department of Agriculture. National agricultural statistics service. Oklahoma agricultural statistics; 2013.

[26] Jessen H [Internet]. Energy Beets: Who will Leap First? ; 2012 [Updated 11.04.12; cited 06.11.14] Available from: http://www.ethanolproducer.com/articles/8707/energy-beetswho-will-leap-first.

[27] Zhang N, Green VS, Ge X, Savary BJ, Xu J. Ethanol fermentation of energy beets by self-flocculating and non-flocculating yeasts. Bioresour Technol 2014 Mar;155:189-197.

[28] Katz JP, Boland MA. One for all and all for one? A new generation of co-operatives emerges. Long Range Plan 2002;35(1):73-89.

[29] Jensen KL, Clark CD, English BC, Menard RJ. Preferences for marketing arrangements by potential switchgrass growers. J Coop 2011;25(2):16-43.

[30] Black JR, Barnett BJ, Hu Y. Cooperatives and capital markets: the case of MinnesotaDakota sugar cooperatives. American journal of agricultural economics 1999;81(5):124046 
[31] Bittner JB [Internet]. Co-Op plans to put dough into crops of wheat farmers. 1999 [Updated 09.08.99; cited 09.12.14] Available from: http://newsok.com/co-op-plans-toput-dough-into-crops-of-wheat-farmers/article/2664488.

[32] Libsack S. Energy Beets -Pipeline to Biofuel Feedstock. 2010. Available from: http://biofuelsconnect.crowdvine.com/attachments/0003/9571/Libsack_Steve.pdf [Accessed January 2013].

[33] Tembo G, Epplin FM, Huhnke RL. Integrative investment appraisal of a lignocellulosic biomass-to-ethanol industry. J Agric Resour Econ 2003;28(3):611-33.

[34] Mapemba LD. Cost to deliver lignocellulosic biomass to a biorefinery [Dissertation]. Stillwater, OKlahoma: Oklahoma State University; 2005.

[35] Haque M, Epplin FM. Cost to produce switchgrass and cost to produce ethanol from switchgrass for several levels of biorefinery investment cost and biomass to ethanol conversion rates. Biomass Bioenerg 2012 Nov;46:517-30.

[36] Schlenker W, Roberts MJ. Nonlinear effects of weather on corn yields. Appl. Econ. Perspect. Pol. 2006;28(3):391

[37] Yu T, Babcock BA. Estimating non-linear weather impacts on corn yield: A bayesian approach. Center for Agricultural and Rural Development, Iowa State University; 2011

[38] Vagh Y. An investigation into the effect of stochastic annual rainfall on crop yields in South Western Australia. International Conference on Knowledge Discovery, Bali; 2012.

[39] Freckleton R, Watkinson A, Webb DJ, Thomas T. Yield of sugar beet in relation to weather and nutrients. Agric forest meteorol 1999 Sept;93:39-51.

[40] U.S. Department of Agriculture. Census of agriculture. In:Geographic Area Series, vol. 1. Oklahoma State and county data; 2009. part 51.

[41] Hwang S, Epplin FM, Lee B, Huhnke R. A probabilistic estimate of the frequency of mowing and baling days available in Oklahoma USA for the harvest of switchgrass for use in biorefineries. Biomass Bioenerg 2009;33(8):1037-45.

[42] Pates M [Internet]. Self-propelled beet harvesters showcased at sugar beet institute. 2013 [Updated 03.13; cited 11.06.14] Available from: http://www.agweek.com/event/article /id/20660/

[43] Wang C. Economic analysis of delivering switchgrass to a biorefinery from both the farmers' and processor's perspectives [Master's thesis]. Knoxville, Tennessee: University of Tennessee; 2009.

[44] Dysert LR. Sharpen your cost estimating skills. Cost Engineering 2003;45(6):22-30.

[45] Gallagher PW, Brubaker H, Shapouri H. Plant size: capital cost relationships in the dry mill ethanol industry. Biomass Bioenerg 2005;28(6):565-71.

[46] ICIS News [Internet]. Abengoa opens US cellulosic ethanol plant in Kansas. 2014 [Updated 10.14; cited 09.01.15] Available from: http://www.icis.com/ resources /news/2014/10/17/9830010/abengoa-opens-us-cellulosic-ethanol-plant-in-kansas/.

[47] Hofstrand D, Johanns A. Tracking ethanol profitability. Agricultural Marketing and Resource Center, January Ames, IA .2008. Available from: http://www.extension.iastate. edu/agdm/energy/html/d1-10.html [Accessed December 2014] 
[48] Eidman VR. Ethanol economics of dry mill plants. In: Corn based ethanol in Illinois and the U.S. Dept. Agr. and Cons.Econ., University of Illinois; 2007 [chapter 3]. Available from: http://www.farmdoc.illinois.edu/policy/research_reports/ethanol_report/Ethanol \%20Report.pdf [Accessed November 2014]

[49] Kaylen M, Van Dyne DL, Choi Y-S, Blasé M. Economic feasibility of producing ethanol from lignocellulosic feedstocks. Bioresour Technol 2000;72(1):19-32.

[50] Farahmand K, Dharmadhikari N, Khiabani V. Analysis of transportation economics of sugar-beet production in the Red River Valley of North Dakota and Minnesota using Geographical Information System. J Renew Agric 2013;1(7):126-131. 
Table 1 . Regression estimates for industrial beet yield $\left(\mathrm{Mg} \mathrm{ha}^{-1}\right)$ response to annual rainfall (2011-2013) in Oklahoma

\begin{tabular}{lccl}
\hline Variable & Estimate & Standard Error & P value \\
\hline Intercept & 24.21 & 77.68 & 0.75 \\
Location Grady & -21.86 & 8.15 & $0.01^{* *}$ \\
Location Caddo & -29.12 & 5.50 & $0.00^{* *}$ \\
Mean Temp $^{\text {a }}$ & 1.72 & 4.25 & 0.68 \\
Rainfall $^{\mathrm{b}}$ & 0.25 & 0.36 & 0.48 \\
Adj R-Squared & $46 \%$ & &
\end{tabular}

${ }^{* *}$ Significant at $5 \%$ probability level

${ }^{a}$ Average daily temperature $\left({ }^{0} \mathrm{C}\right)$ from October to August, May and June in 2011, 2012 and 2013 respectively at each location was obtained from:

http://www.mesonet.org/index.php/weather/station_monthly_summaries

${ }^{\mathrm{b}}$ Total monthly rainfall data $(\mathrm{cm})$ from September to August, May and June in 2011, 2012 and 2013 respectively at each location was obtained from:

http://www.mesonet.org/index.php/weather/monthly_rainfall_table/stil 
Table 2. No-till budget for producing glyphosate-tolerant industrial beets in Oklahoma (ha)

\begin{tabular}{|c|c|c|c|c|}
\hline Item & Unit & $\begin{array}{c}\text { Price per } \\
\text { unit }\end{array}$ & Quantity & Value \\
\hline Land rental & ha & 158.08 & 1 & 158.08 \\
\hline Sugar beet seed & $\mathrm{kg}$ & 76.73 & 5 & 345.29 \\
\hline Herbicide (glyphosate $3 x$ ) & $\mathrm{kg}$ & 8.11 & 4 & 36.33 \\
\hline Urea $(46-0-0)$ & $\mathrm{kg}$ & 0.44 & 196 & 86.24 \\
\hline $\operatorname{DAP}^{\mathrm{a}}(18-46-0)$ & $\mathrm{kg}$ & 0.60 & 122 & 73.02 \\
\hline Seeding no-till planter & ha & 36.16 & 1 & 36.16 \\
\hline Fertilizer application & ha & 10.43 & 1 & 10.43 \\
\hline Herbicide application & ha & 13.47 & 2 & 26.94 \\
\hline Beet harvester & ha & 188.76 & 1 & 188.76 \\
\hline Transportation to facility & ha & 182.8 & 1 & 182.80 \\
\hline Annual operating capital & $\$$ & 0.07 & 772 & 54.07 \\
\hline Total cash costs & ha & & & 1198.12 \\
\hline
\end{tabular}


Table 3. Assumptions to model an industrial beet biorefinery in Oklahoma

\begin{tabular}{|c|c|c|c|}
\hline Item & Unit & Base & Source \\
\hline Capacity adjustment factor $^{\mathrm{a}}$ & & 0.5 & Haque and Epplin [35] \\
\hline Capital cost adjustment factor ${ }^{\mathrm{b}}$ & & 1.66 & Dysert [44] \\
\hline \multicolumn{4}{|l|}{ Biorefinery capital investment } \\
\hline 38 dam $^{3}$ per year processed in 300 days $^{c}$ & \$ million & 46 & Ripplinger [21] \\
\hline 76 dam $^{3}$ per year processed in 300 days $^{\mathrm{d}}$ & \$ million & 77 & \\
\hline $152 \mathrm{dam}^{3}$ per year processed in 300 days & \$ million & 128 & \\
\hline Operation and maintenance cost (processing) & $\$ \mathrm{~m}^{-3}$ & 164 & Shapouri and Salassi [16] \\
\hline Project life & years & 20 & Haque and Epplin [35] \\
\hline Discount rate & $\%$ & 15 & Kaylen et al. [49] \\
\hline Conversion rate ${ }^{\mathrm{e}}$ & $\mathrm{dm}^{3} \mathrm{Mg}^{-1}$ & 110 & $\begin{array}{l}\text { Maung and Gustafson } \\
\text { [19] }\end{array}$ \\
\hline Plant operational days per year ${ }^{\mathrm{f}}$ & no. & 300 & Ripplinger [21] \\
\hline Truckload & $\mathrm{Mg}$ & 27 & Farahmand et al. [50] \\
\hline Harvest machine $\mathrm{g}^{\mathrm{g}}$ & $\$ 000$ & 785 & Pates [42] \\
\hline Harvest machine throughput & ha $h r^{-1}$ & 3 & Pates [42] \\
\hline
\end{tabular}

${ }^{\mathrm{a}} \mathrm{A}$ factor of 0.5 is used to scale the processing facility capacities up/down to other plant sizes

${ }^{\mathrm{b}}$ Following Dysert [44], it was assumed that doubling plant size will increase construction costs by about $66 \%$ based on a 0.73 proration factor.

${ }^{c}$ Estimate by Ripplinger [21] is $70 \mathrm{M} \$$ for a $152 \mathrm{dam}^{3}$ per year plant with a processing window of 330 days. Our beet plant would cost $77 \mathrm{M} \$$ in capital investment cost for a 10 month processing window.

${ }^{\mathrm{d}}$ Computation based on the cost adjustment factor of 1.6586 .

${ }^{\mathrm{e}}$ Implicitly, an average refined sugar recovery rate of $18 \%$ per $\mathrm{Mg}$ of beets [13] and $588 \mathrm{dm}^{3} \mathrm{Mg}^{-}$ 1 of refined sugar [16] was assumed.

${ }^{\mathrm{f}} \mathrm{A} 10$ month harvest window and 10 month processing season (just-in-time biomass delivery for processing).

${ }^{\mathrm{g}}$ Agrifac (Holmer exxact HexxTraxx) $447 \mathrm{~kW}$ self-propelled 12 row, $0.56 \mathrm{~m}$ row-width, $25.4 \mathrm{Mg}$ tank, beet harvester with an estimated throughput of three ha per hour. 
Table 4. Estimates of the breakeven price of ethanol from industrial beets for three land proportions and three levels of biorefinery investment cost ${ }^{\mathrm{a}}$

\begin{tabular}{cccc} 
& \multicolumn{3}{c}{ Proportion of land allocated to beet production per year } \\
\cline { 2 - 4 } & $5 \%$ & $10 \%$ & $20 \%$ \\
\hline Investment cost (\$ million) & & At $15 \%$ discount rate $\$ \mathrm{~m}^{-3}$ & \\
64 & 542 & 518 & 510 \\
128 & 610 & 586 & 579 \\
256 & 745 & 724 & 713 \\
\hline Investment cost (\$ million) & & At $7.5 \%$ discount rate $\$ \mathrm{~m}^{-3}$ & \\
64 & 515 & 494 & 583 \\
128 & 557 & 536 & 526 \\
256 & 642 & 618 & 610 \\
\hline
\end{tabular}

${ }^{\mathrm{a}}$ Breakeven ethanol price was defined as the price at which the net present value of the production process is zero. The cost estimates reported here excludes potential byproduct credit of $79 \$ \mathrm{~m}^{-3}$. 
Table 5. Cost components of the breakeven price of ethanol from industrial beets for three levels of land proportions and three levels of investment cost

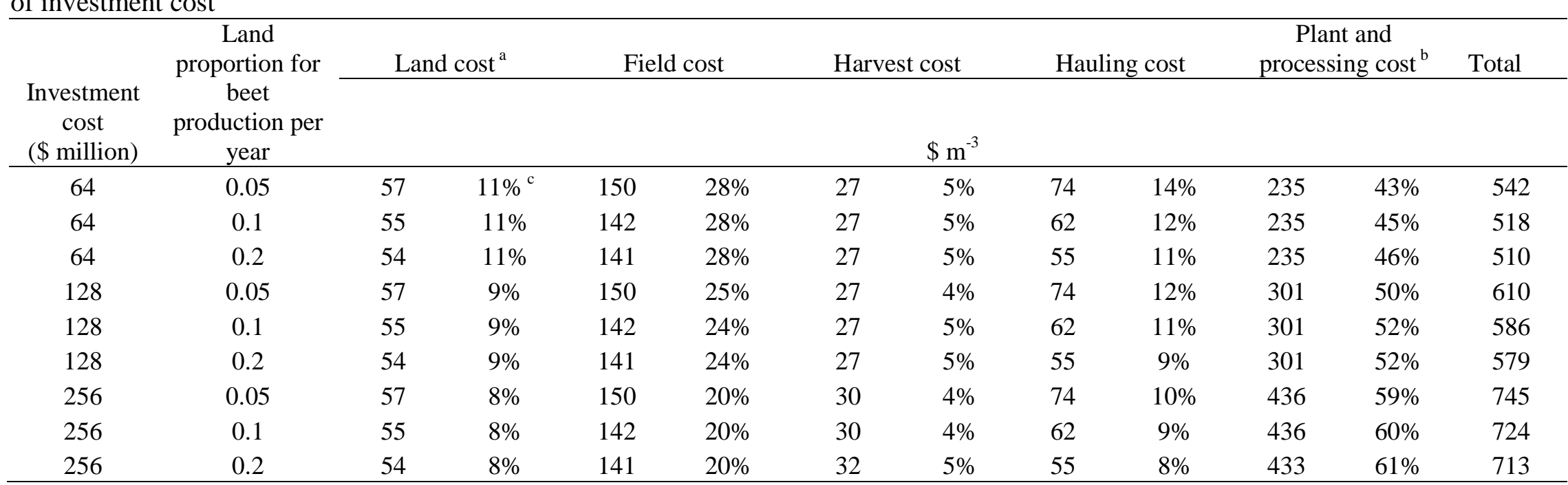

${ }^{a}$ Land rental cost includes compensation for delaying harvest beyond September.

${ }^{\mathrm{b}}$ Plant and processing cost includes cost of investment and an operating and maintenance cost of $164 \$ \mathrm{~m}^{-3}$.

${ }^{\mathrm{c}}$ Percentage of total cost per $\mathrm{m}^{3}$ of ethanol production. 
Table 6. Estimates of the cost to deliver a steady flow of industrial beets at various conversion rates, land, fuel, and yield scenarios

\begin{tabular}{|c|c|c|c|c|c|c|}
\hline \multirow[t]{2}{*}{ Item } & \multicolumn{3}{|c|}{$\begin{array}{l}\text { Proportion of land allocated to beet } \\
\text { production per year }\end{array}$} & \multirow[b]{2}{*}{$\begin{array}{l}25 \% \text { lower } \\
\text { yield }\end{array}$} & \multirow{2}{*}{$\begin{array}{c}50 \% \\
\text { higher } \\
\text { yield }\end{array}$} & \multirow[b]{2}{*}{$\begin{array}{c}\text { Double land } \\
\text { price }\end{array}$} \\
\hline & $\begin{array}{l}10 \% \\
\text { (Base) }\end{array}$ & $5 \%$ & $20 \%$ & & & \\
\hline Harvested area ha & 31,748 & 33,499 & 31,402 & 41,540 & 21,255 & 31,645 \\
\hline Total beets harvested $\mathrm{Mg}(000)$ & 1,374 & 1,374 & 1,374 & 1,374 & 1,374 & 1,374 \\
\hline Land rent $\$ \mathrm{Mg}^{-1}$ & 5.94 & 6.17 & 5.85 & 7.74 & 3.98 & 11.83 \\
\hline Field production cost $\$ \mathrm{Mg}^{-1}$ & 15.45 & 16.30 & 15.28 & 20.21 & 10.34 & 15.40 \\
\hline Harvest cost $\$ \mathrm{Mg}^{-1}$ & 2.91 & 2.91 & 2.91 & 2.91 & 2.91 & 2.91 \\
\hline $\begin{array}{l}\text { Transportation cost } \$ \mathrm{Mg}^{-1} \\
\text { Total cost of delivered beets } \$\end{array}$ & 6.71 & 8.01 & 5.91 & 8.10 & 6.05 & 6.79 \\
\hline $\mathrm{Mg}^{-1}$ & 31.01 & 33.39 & 29.96 & 38.96 & 23.28 & 36.92 \\
\hline
\end{tabular}




\begin{tabular}{|c|c|c|c|c|c|c|c|c|c|c|c|c|}
\hline Crop/Month & Oct & Nov & Dec & Jan & Feb & Mar & Apr & May & Jun & Jul & Aug & Sept \\
\hline \multicolumn{13}{|l|}{ Year 1} \\
\hline Beets & \multirow{2}{*}{\multicolumn{2}{|c|}{ Seed beets }} & & & & & & & \multirow{2}{*}{\multicolumn{4}{|c|}{ Harvest beets ${ }^{\mathrm{b}}$}} \\
\hline & & & & & & & & & & & & \\
\hline \multicolumn{13}{|l|}{ Year 2} \\
\hline \multirow{2}{*}{\multicolumn{13}{|c|}{ Harvest beets }} \\
\hline & & & & & & & & & & & & \\
\hline Sorghum & & & & & & & \multicolumn{2}{|c|}{$\begin{array}{c}\text { Seed } \\
\text { Sorghum }\end{array}$} & & $\rightarrow$ & \multicolumn{2}{|c|}{$\begin{array}{l}\text { Harvest } \\
\text { Sorghum }\end{array}$} \\
\hline \multicolumn{13}{|l|}{ Year 3} \\
\hline \multirow[t]{2}{*}{ Wheat } & \multirow{2}{*}{\multicolumn{2}{|c|}{$\begin{array}{c}\text { Seed } \\
\text { Wheat }\end{array}$}} & & & & & \multirow[b]{2}{*}{$\rightarrow$} & & \multirow{2}{*}{$\begin{array}{c}\text { Harvest } \\
\text { Wheat }\end{array}$} & & & \\
\hline & & & & & & & & & & & & \\
\hline
\end{tabular}

Figure1. Schedule for a potential industrial beet-sorghum-wheat 3-year crop rotation in Oklahoma $^{\mathrm{a}}$

${ }^{\text {a }}$ In year 1, industrial beets would be seeded in October with harvest beginning in June and extending through to March of the second year. A summer sorghum crop would be produced in year 2. In year 3, wheat could be seeded in October with harvest beginning June.

${ }^{\mathrm{b}}$ If beets are harvested during the June through September period, the land could be seeded to a fall crop enabling a beet-canola-wheat rotation. 


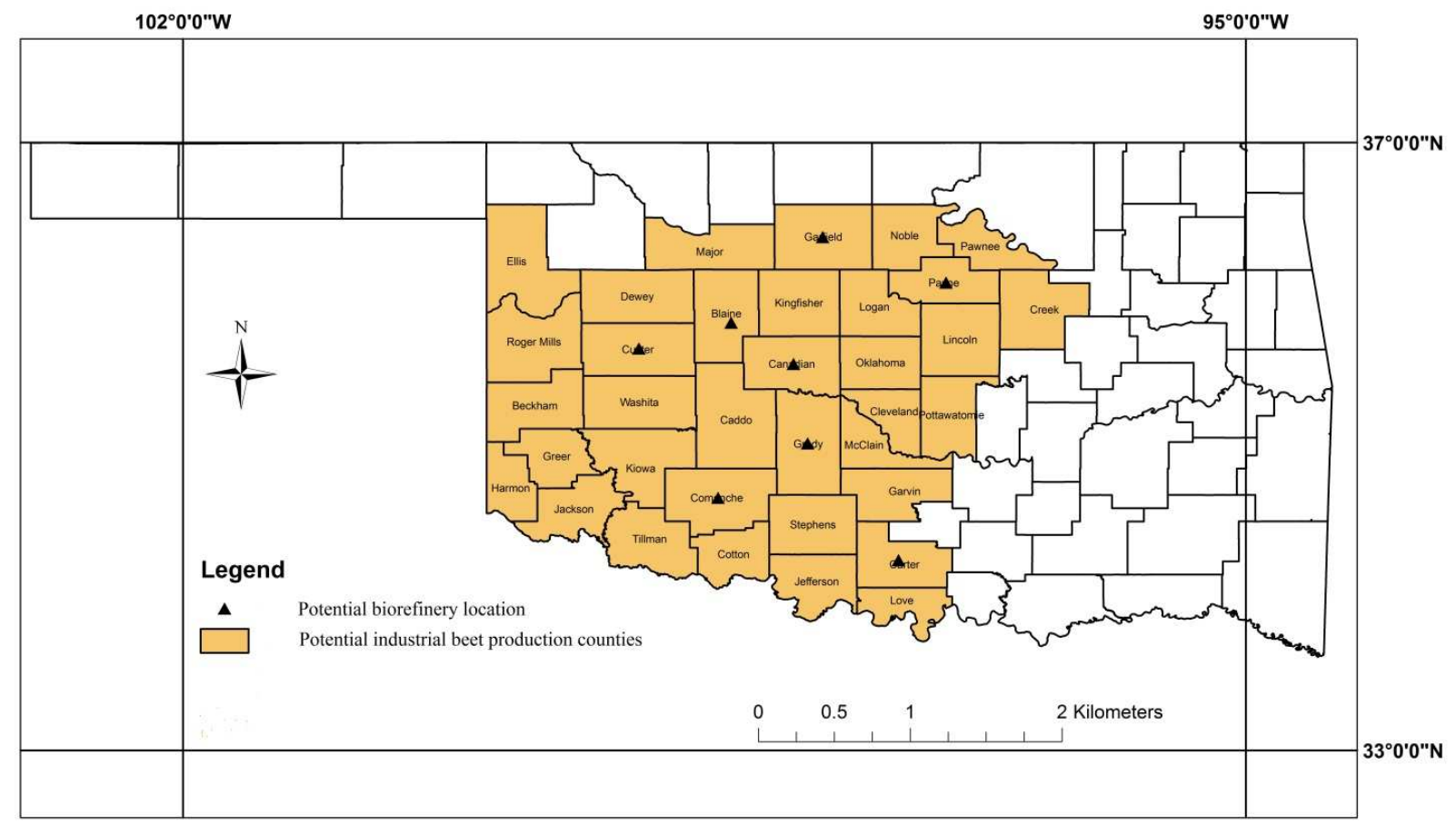

Figure 2. Potential production regions and biorefinery locations for industrial sugar beets in Oklahoma 

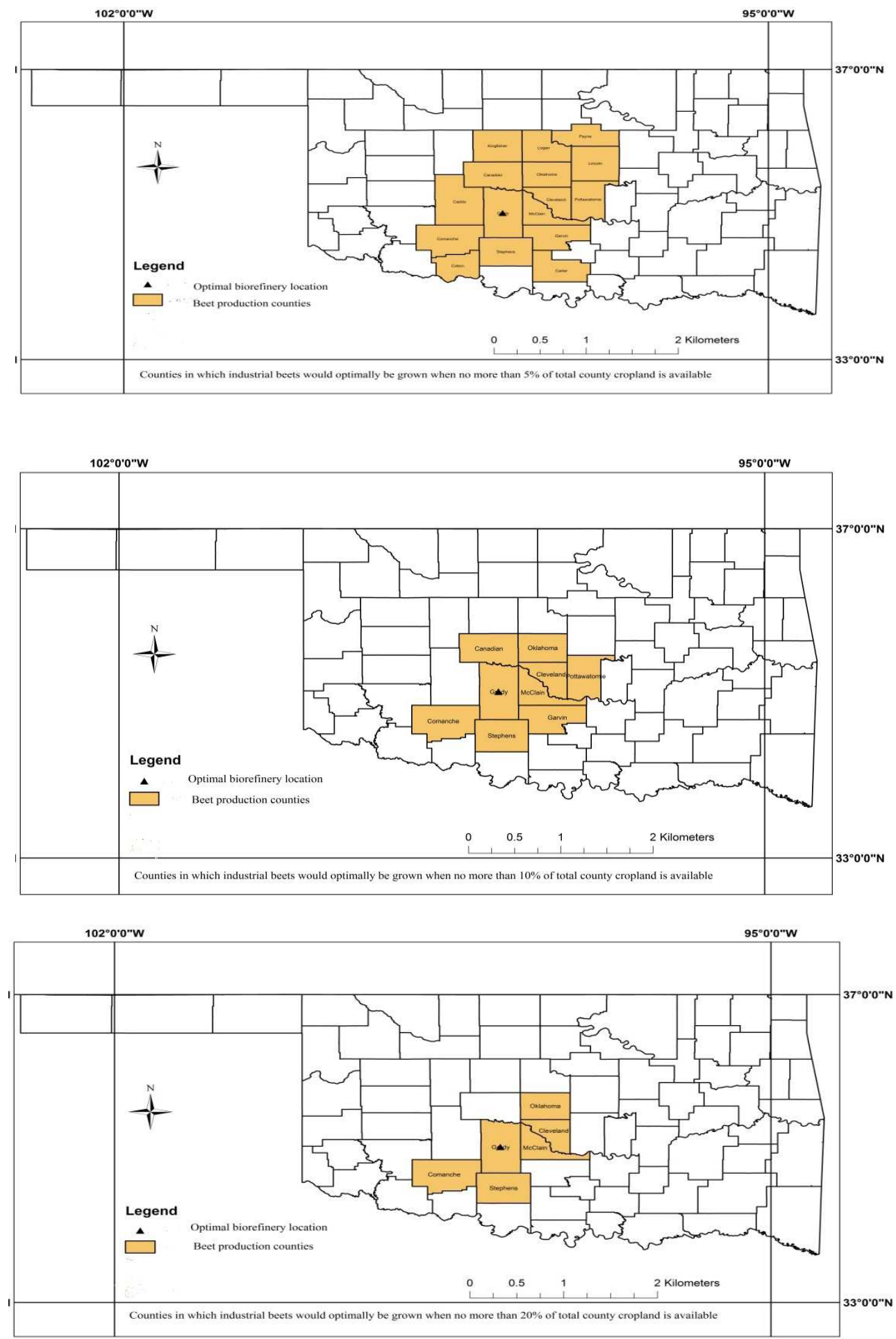

Figure 3. Optimal Oklahoma biorefinery location and counties for optimal beet production for a biorefinery capital cost of $\$ 128$ million and for land used for beets limited to 5\%,10\%, and $20 \%$ of available cropland in each county per year. 
Table A2. Description of Variables

\begin{tabular}{ll}
\hline Variable & Description \\
\hline$N P V$ & Net present value of the system (\$) \\
$Q_{j s m}$ & Quantity of ethanol produced in month $m$ by a biorefinery of size $s$ at \\
& location $j\left(\mathrm{~m}^{3}\right)$ \\
$A_{i m}$ & Land harvested in month $m$ in county $i(\mathrm{ha})$ \\
$X T_{i j s m}$ & Beets transported from county $i$ in month $m$ to a biorefinery of size $s$ at \\
& location $j(\mathrm{Mg})$ \\
$H$ & Integer variable representing the total number of beet harvesters \\
$X_{i m}$ & Beets harvested in month $m$ in county $i(\mathrm{Mg})$ \\
$X P_{j s m}$ & Beets processed in month $m$ for biorefinery of size $s$ at location $j(\mathrm{Mg})$ \\
$X H_{i m}$ & Proportion of a beet harvester used in month $m$ in county $i$ \\
$\beta_{j s}$ & Binary variable for biorefinery of size $s$ at location $j(1$ if built, 0 otherwise) \\
\hline
\end{tabular}


Table A3. Description of parameters

\begin{tabular}{ll}
\hline Parameter & Description \\
\hline$\rho$ & Price of ethanol $\left(\$ \mathrm{~m}^{-3}\right)$ \\
$\delta$ & Cost of producing beets except harvest cost $\left(\$ \mathrm{ha}^{-1}\right)$ \\
$\tau_{i j}$ & Round-trip cost of transporting beets from county $i$ to biorefinery located at $j\left(\mathrm{Mg}^{-1}\right)$ \\
$\gamma$ & Cost of a beet harvester $(\$)$ \\
$\lambda$ & Quantity of ethanol produced from a $\mathrm{Mg}$ of beet feedstock $\left(\mathrm{m}^{3} \mathrm{Mg}^{-1}\right)$ \\
$B I P R O P$ & Proportion of cropland in each county available for producing beets \\
$P O T A C R E_{i}$ & Total ha of cropland in county $i$ \\
$Y A D_{m}$ & Beet yield adjustment factor for beets harvested in month $m$ \\
$B Y L D_{i}$ & Beet yield from production in county $i\left(\mathrm{Mg}\right.$ ha $\left.\mathrm{yr}^{-1}\right)$ \\
$O M C_{s}$ & Biorefinery operating and maintenance cost of size $s\left(\$ \mathrm{yr}^{-1}\right)$ \\
$A F C_{s}$ & Biorefinery investment cost for facility of size $s$ made once in year zero $(\$)$ \\
$P V A F$ & Present value of annuity \\
$T$ & Biorefinery life (years) \\
$r$ & Discount rate (\%) \\
$C A P P_{s}$ & Processing capacity of the biorefinery of size $s\left(\mathrm{~m}^{3}\right.$ of ethanol per month) \\
$F W D_{i m}$ & Field work days suitable for harvesting in county $i$ in month $m$ \\
$D C A P H_{m}$ & Daily capacity of a beet harvester in month $m$ \\
$C A P H_{m}$ & Capacity of harvester in month $m$ \\
\hline
\end{tabular}

